\title{
Non-invasive focal therapy of organ confined prostate cancer with magnetic resonance guided focused ultrasound surgery
}

\author{
Alessandro Napoli, Fulvio Zaccagna, Pier Luigi Di Paolo, Francesco Sandolo, Carola Palla, Fabrizio Andrani, \\ Carlo Catalano \\ From Current and Future Applications of Focused Ultrasound 2014. 4th International Symposium \\ Washington, D.C, USA. 12-16 October 2014
}

\section{Background/introduction}

To assess safety and effectiveness of non-invasive high intensity 3T MR guided Focused Ultrasound Surgery (MRgFUS) treatment of localized prostate cancer as salvage therapy and as an alternative to active surveillance.

\section{Methods}

14 patients with biopsy proven focal $\mathrm{T} 2$ prostate cancer (low-to-intermediate risk: PSA max 12 and Gleason max $3+4)$, confirmed on a previous multiparametric MR exam (Discovery 750, GE) including dynamic contrast enhanced (DCE) imaging (Gd-BOPTA, Bracco), underwent MRgFUS ablation (ExAblate, InSightec). 1 patient had already performed radiotherapy without clinical success, 1 patient underwent US-guided Focused Ultrasound treatment with residual tumour tissue inside the gland needing a second treatment; the last 2 enrolled patients were part of an active surveillance regimen. All patients refused radical laparoscopic prostatectomy. MRgFUS treatment was carried out on the MR identifiable lesion $(\max 2)$ using a patient specific energy (3000-8500 J) and real time MR thermometry monitor for correct treatment location. Non-perfused volume (NPV) in the post-ablative MRI was used for necrosis assessment.

\section{Results and conclusions}

Results: No significant complications were observed in all subjects during or immediately after the procedure. Post-treatment MRI demonstrated extensive coagulative necrosis at the site of sonication. At follow-up examinations 3 patients were free of residual viable tumor within

University of Rome - Sapienza, Rome, Italy the treated area; in the remaining patient, $10 \%$ of residual tumor was observed within the NPV. There was a variable amount of isolated cancer tissue (Gleason $\max 7,3+4)$ within the non-treated parenchyma that was neither identifiable at MRI nor at biopsy.

Conclusion: Our results suggest that MR guided Focused Ultrasound Surgery is a safe and effective modality to determine $>90 \%$ necrosis of identifiable prostate cancer; other prospective studies are needed to extend success rate in larger cohort.

Published: 30 June 2015

doi:10.1186/2050-5736-3-S1-P84

Cite this article as: Napoli et al:: Non-invasive focal therapy of organ confined prostate cancer with magnetic resonance guided focused ultrasound surgery. Journal of Therapeutic Ultrasound 2015 3(Suppl 1):P84.

Submit your next manuscript to BioMed Central and take full advantage of:

- Convenient online submission

- Thorough peer review

- No space constraints or color figure charges

- Immediate publication on acceptance

- Inclusion in PubMed, CAS, Scopus and Google Scholar

- Research which is freely available for redistribution 